\title{
A New Device to Select Microcarriers for Biomass Immobilization: Application to an Anaerobic Consortium
}

\author{
M. Madalena Alves, M. Alcina Pereira, J. Maggiolly Novais, F. Fdz Polanco, M. Mota
}

\begin{abstract}
A new device was designed to compare the biomass retention capacity of different microcarriers. Microcarriers were placed in as many as 28 independent, parallel minibioreactors under selected and identical flow conditions. Sepiolite, pozzolana, clay, and foam glass (Poraver ${ }^{\mathrm{TM}}$ ) were examined for biomass retention capacity, characterized in terms of attached volatile solids and specific methanogenic activity, and examined with scanning electron microscopy. Sepiolite had the greatest biomass retention capacity and better internal porous volume for biomass immobilization. The specific methanogenic activity of the immobilized biomass in different materials was found to be inversely correlated to the amount of attached biomass. A maximum difference of $19 \%$ overall activity of the colonized material was observed between foam glass and pozzolana. Compared with the suspended biomass, a clear enhancement of syntrophic activity (up to $110 \%$ ) and reduction of acetoclastic activity (up to 73\%) was observed in the biofilm. This system of examination provides information useful for preselecting microcarriers for biomass colonization. Water Environ. Res., 71, 209 (1999).
\end{abstract}

KEYWORDS: microcarriers, anaerobic fluidized-bed reactor, biomass immobilization, methanogenic activity.

Biomass can be retained in anaerobic treatment systems by attachment to fixed or moving solid supports. In anaerobic filters, biomass immobilization is achieved by retaining biomass in the void space of a matrix where it adheres to the matrix surface. In fluidized-bed reactors, a biofilm is established on the surface of a solid support (i.e., a microcarrier), typically small spherical particles that are porous or nonporous. Sand is the most widely used microcarrier in fluidized-bed reactors (Heijnen et al., 1986) but is far from optimal in terms of its biomass retention capacity. Other materials have been evaluated, such as granular activated carbon (Fox et al., 1990), foam glass (Jördening, 1992), sepiolite (Balaguer et al., 1992, and Garcia-Calderón et al., 1996), diatomaceous earth (Schraa and Jewell, 1984, and Yee et al., 1992), pumice stone (Balaguer et al., 1991), and pozzolana (Garcia-Calderón et al., 1996). The use of porous microcarriers reduced start-up time to less than 50\% that of sand (Yee et al., 1992). Jördening (1992) concluded that foam glass, if colonized before inoculation of an anaerobic fluidized-bed reactor, was more efficient than sand, allowing the application of higher organic loading rates and favoring biofilm growth.

A quick, strong, and uniform attachment of bacteria to the support surface is essential. Attachment depends on the surface physicochemical properties (Rouxhet and Mozes, 1990, and Yee et al., 1992) although the shear stress is also a determinant factor in biofilm development (Bryers, 1987, and Rittmann, 1982). It is generally accepted that a porous or rough surface is better for biofilm development than a smooth surface. Huysman et al. (1983) reported the importance of the availability of niches suitably sized to retain bacterial microcolonies. Surface roughness and internal pore space may protect against detachment of immobilized cells by hydraulic shear stress (Bryers, 1987), but Petrozzi et al. (1991) claim that, for colonization purposes, surface roughness is more important than internal surface area. Messing and Oppermann (1979) concluded that, to accumulate large quantities of biomass, pore sizes should range between the smallest cell dimension and five times its largest dimension and Shimp and Pfaender (1982) also reported that microbially sized crevices favor surface colonization. Wang and Wang (1988) used a simple mathematical model to determine that a pore diameter of two to five times the cell diameter produced the maximum immobilized cell loading.

Bacteria retained in the internal surface area or inside a niche may encounter diffusional resistance to the flux of substrates and products (Huysman et al., 1983). Biogas accumulation inside the microcarrier can induce washout of colonized particles, affecting overall performance. However, use of porous carriers with large internal porous volume and large pores can overcome this problem because internal convective flow can also mediate the transport of metabolites.

The type of support material used can influence methanogenic activity because of possible chemical interactions between the material, the bulk liquid, and the bacteria (Bonastre and Paris, 1988; Maestrojuán and Fiestas, 1988; Muñoz et al., 1994; and Murray and Van den Berg, 1981). On the other hand, substrate composition greatly influences microbial adhesion so the choice of a support for microbial colonization should also consider the substrate. Yee (1990) suggests that substrates resulting in faster growing and higher yielding biofilm cultures are less sensitive to the microcarrier characteristics. In turn, slow-growing and lowyielding biofilms should benefit from immobilization on porous microcarriers. Borja et al. (1994) reported that the addition of sepiolite enhanced the digestion of milk bottling waste whereas the addition of bentonite promoted the digestion of abattoir waste and proposed an explanation of these effects based on the different chemical composition of the two wastewaters.

To date, comparative studies of different microcarriers for biomass colonization have been made either in continuous mode, that is, operating one reactor with each type of support (Fox et al., 1990, and Yee et al., 1992), or in batch tests (Bonastre and Paris, 1988, and Maestrojuán and Fiestas, 1988). Although the former methodology provides the most directly applicable data for any particular situation (substrate composition, temperature, operating mode), it is difficult to operate several anaerobic fluidized-bed reactors in parallel, especially when long-term operation is to be 


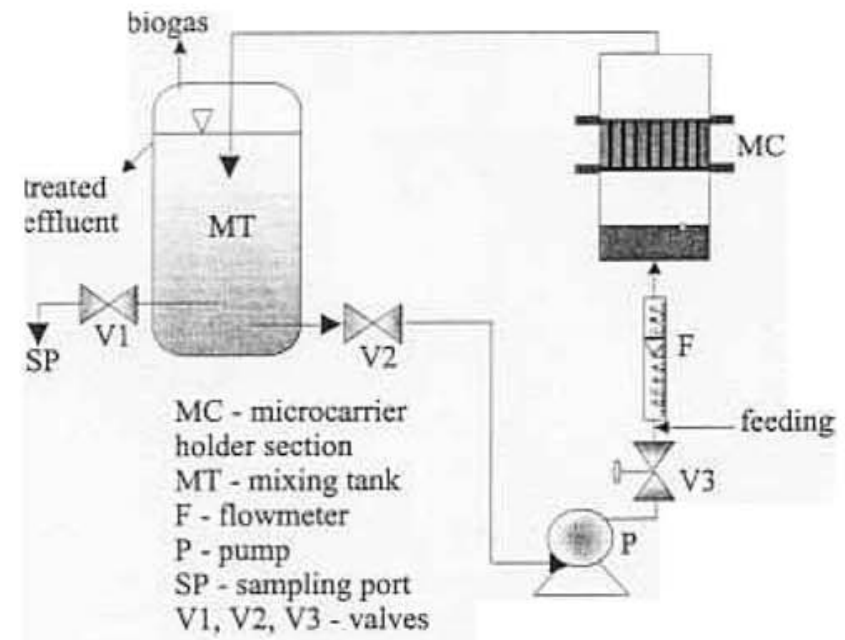

Figure 1-Experimental set up.

evaluated. On the other hand, comparison of colonization properties in batch assays does not account for the fluid-particle upflow or downflow conditions present in a real reactor and may be a poor system for determining biofilm formation requirements.

In this work, a methodology based on the simultaneous installation of all supports in the same bioreactor was tested, with identical flow conditions provided for all of the assayed supports. The same concept has already been applied to the study of biomass-support interactions and biomass growth in anaerobic filters (Alves et al., 1998). Four porous materials were studied in terms of long-term colonization capacity and specific methanogenic activity of the retained biomass to obtain a set of results that would allow preselection of support materials for further use in anaerobic treatment systems.

\section{Materials and Methods}

Experimental Set Up. The reactor, with a total volume of $35 \mathrm{~L}$, was constructed with Plexiglas and is schematically represented in Figure 1. The different supports were placed in a total of 28 parallel minibioreactors, each with $40 \mathrm{~mL}$ volume (diameter $=2.5$ $\mathrm{cm})$. Supports were randomly distributed in the microcarrier (MC) section of the reactor $($ volume $=2.84 \mathrm{~L}$, diameter $=19 \mathrm{~cm}$ ). A grid covered the tops of all of the minibioreactors. A centrifugal pump, needle valve, and flowmeter allowed the desired upflow velocity through the MC section to be selected. Feed was introduced before the MC section and treated effluent was removed with biogas from the mixing tank. Below the MC section, there is a flow stabilization compartment with a fixed bed of glass balls, which helps homogenize the upflow velocity. Above the MC section another compartment was constructed to separate the microcarriers from the effect of sudden pipe contraction.

Preliminary Experiment: Flow Distribution in the Microcarrier Section. A preliminary experiment was conducted with two support materials (clay and foam glass) randomly distributed in the MC section as shown in Figure 2. Twelve minibioreactors (6 reactors of each support material) were randomly placed in the inner core of the MC section and 16 minibioreactors ( 8 reactors of each support type) were placed in the outer layer. Both the average particle diameter and the applied upflow superficial velocity were similar to those used in the actual experiment. The operation was

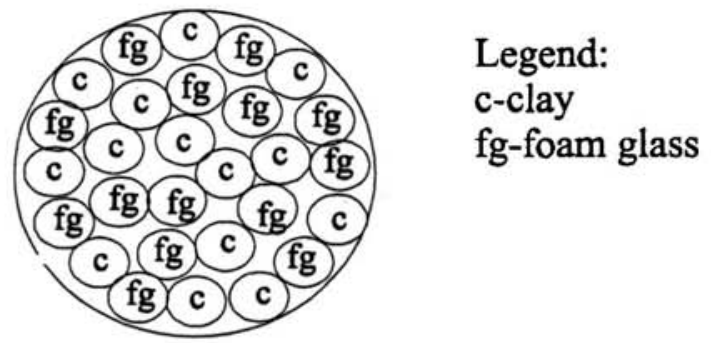

Figure 2-Microcarrier distribution in the MC sectiot (preliminary experiment).

carried out in batch, total recycle mode. A volatile fatty acid (VFA) based substrate between 1200 and $3000 \mathrm{mg}$ chemica oxygen demand (COD)/L was maintained over a 30-day tria period by successive additions. Figure 3 represents the averag attached biomass on each type of support and the associated $95 \%$ confidence interval in the inner and outer regions of the MC section. It was concluded that the differences in attached biomas as a result of minibioreactor location were not significant and $\mathrm{n}$ general trend was observed.

Microcarriers and Bed Characteristics. In this experiment four porous microcarriers were tested: sepiolite, foam glass (Po raver ${ }^{\mathrm{TM}}$ ), clay, and pozzolana. Table 1 summarizes some of thei: relevant characteristics. The dry grain density was measured b: mercury picnometry. The wet grain density was determined usin: water picnometry after forcing water into the pores of each mate rial. Water-accessible porosity was considered more suitable thai total porosity for characterizing the ability of each material fo internal microbial colonization. Before start up, all materials wert submitted to 2 hours calcination at $550^{\circ} \mathrm{C}$ and a 30 -minutc autoclave sterilization at $121{ }^{\circ} \mathrm{C}$. For some materials, pH stabili. zation was needed.

Microcarriers were randomly distributed inside the MC sectior as shown in Figure 4. Six minibioreactors were filled with eact material. As there was room for 28 parallel minibioreactors, th remaining four minibioreactors were filled with small particles o foam glass for precolonization purposes for another applicatior and to prevent preferential pathways.

Upflow Velocity. The particle size distribution was betweer 3.35 and $4.75 \mathrm{~mm}$ for all materials. The particles were kept in : fixed bed and a superficial upflow velocity of $15 \mathrm{~m} / \mathrm{h}$ was appliec

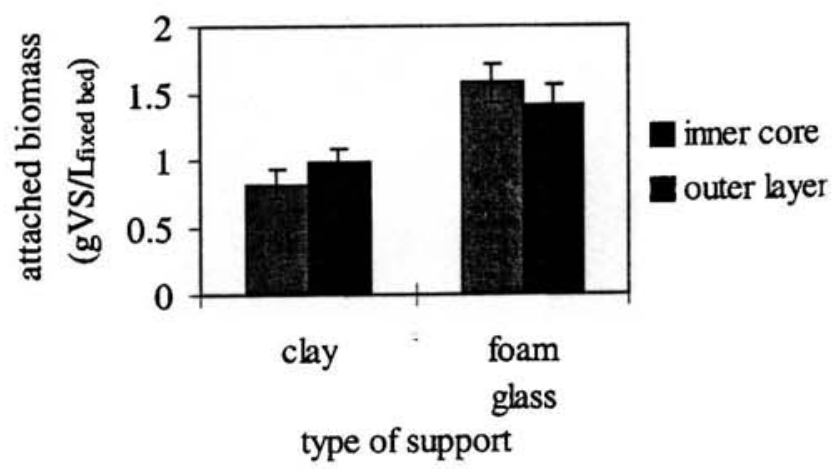

Figure 3-Attached biomass in the preliminary experiment. 
Table 1-Microcarrier characteristics.

\begin{tabular}{|c|c|c|c|c|c|}
\hline Material & $\begin{array}{c}\text { Diameter, } \\
\mathrm{mm}\end{array}$ & $\begin{array}{c}\text { Dry grain } \\
\text { density, } \mathrm{g} / \mathrm{cm}^{3}\end{array}$ & $\begin{array}{c}\text { Wet grain } \\
\text { density, } \mathrm{g} / \mathrm{cm}^{3}\end{array}$ & $\begin{array}{c}\text { Internal } \\
\text { porous* volume, } \\
\mathrm{cm}^{3} / \mathrm{cm}_{\text {(particle) }}^{3}\end{array}$ & $\begin{array}{c}\text { Internal } \\
\text { porous* volume, } \\
\mathrm{cm}^{3} / \mathrm{g}_{\text {(dry weight) }}\end{array}$ \\
\hline Clay & $3.35-4.75$ & $0.714 \pm 0.017$ & $1.094 \pm 0.001$ & $0.381 \pm 0.019$ & $0.534 \pm 0.038$ \\
\hline Foam glass & $3.35-4.75$ & $0.307 \pm 0.012$ & $1.101 \pm 0.013$ & $0.796 \pm 0.016$ & $2.583 \pm 0.130$ \\
\hline Pozzolana & $3.35-4.75$ & $1.532 \pm 0.068$ & $2.039 \pm 0.049$ & $0.508 \pm 0.100$ & $0.333 \pm 0.081$ \\
\hline Sepiolite & $3.35-4.75$ & $0.991 \pm 0.066$ & $1.627 \pm 0.049$ & $0.638 \pm 0.114$ & $0.634 \pm 0.058$ \\
\hline
\end{tabular}

* Water accessible.

in the MC section, a typical value for fluidized-bed reactors operating with porous supports of light materials (Iza et al., 1988).

Substrate and Inoculum. The substrate was made by dilution of skim milk with tap water and was supplemented with macronutrients and micronutrients. Macronutrients were composed of 25 $\mathrm{g} / \mathrm{L}$ magnesium chloride $\left(\mathrm{MgCl}_{2} \cdot 6 \mathrm{H}_{2} \mathrm{O}\right), 28.3 \mathrm{~g} / \mathrm{L}$ potassium ortho-phosphate $\left(\mathrm{KH}_{2} \mathrm{PO}_{4}\right), 45 \mathrm{~g} / \mathrm{L}$ potassium chloride $(\mathrm{KCl})$, and $0.6 \mathrm{~mL}$ of this solution was added per $\mathrm{g}$ COD fed. Micronutrients were composed of $2 \mathrm{~g} / \mathrm{L}$ ferrous chloride $\left(\mathrm{FeCl}_{2} \cdot 6 \mathrm{H}_{2} \mathrm{O}\right), 0.05 \mathrm{~g} / \mathrm{L}$ zinc chloride $\left(\mathrm{ZnCl}_{2}\right), 0.038 \mathrm{~g} / \mathrm{L}$ cupric chloride $\left(\mathrm{CuCl}_{2} \cdot 2 \mathrm{H}_{2} \mathrm{O}\right)$, $0.5 \mathrm{~g} / \mathrm{L}$ manganous chloride $\left(\mathrm{MnCl}_{2} \cdot 4 \mathrm{H}_{2} \mathrm{O}\right), 0.09 \mathrm{~g} / \mathrm{L}$ aluminum chloride $\left(\mathrm{AlCl}_{3} \cdot 6 \mathrm{H}_{2} \mathrm{O}\right), 2 \mathrm{~g} / \mathrm{L}$ cobaltic chloride $\left(\mathrm{CoCl}_{2} \cdot 6 \mathrm{H}_{2} \mathrm{O}\right)$, $0.092 \mathrm{~g} / \mathrm{L}$ nickel chloride $\left(\mathrm{NiCl}_{2} \cdot 6 \mathrm{H}_{2} \mathrm{O}\right), 0.164 \mathrm{~g} / \mathrm{L}$ sodium selenite $\left(\mathrm{Na}_{2} \mathrm{SeO}_{3} \cdot 5 \mathrm{H}_{2} \mathrm{O}\right), 1 \mathrm{~g} / \mathrm{L}$ ethylenediamine tetraacetic acid, $0.2 \mathrm{~g} / \mathrm{L}$ resazurin, and $1 \mathrm{~mL} / \mathrm{L} 36 \%$ hydrochloric acid. The composition of this solution was chosen based on the work of Zehnder et al. (1980). Micronutrients were supplied to the influent feed as $1 \mathrm{~mL} / \mathrm{L}$. Seed sludge was obtained from a municipal digester and $8 \mathrm{~L}$ (24.28 g volatile suspended solids/L) were used for inoculation. A sieve (aperture $=1 \mathrm{~mm}$ ) was used to remove large solids.

Operation Mode. Total recycle was performed for 5 days, after which continuous feeding commenced. Initial influent COD was $2500 \mathrm{mg} / \mathrm{L}$. After 50 days, it was $6000 \mathrm{mg} / \mathrm{L}$. The hydraulic retention time based on the MC section volume was initially 7.4 hours and after 80 days it was changed to 5.3 hours. Routine reactor performance was monitored by measuring influent and effluent $\mathrm{COD}$, influent flow rate, effluent VFA and methane content of the biogas.

After 190 days, operation was stopped, the MC section was opened, and the microcarriers were removed. The contents of each group of six minibioreactors (with the same support material) was mixed, brieffy washed under running water to remove nonattached biomass, then divided into four equal parts, which were placed in $126-\mathrm{mL}$ vials, for methanogenic activity measurement. The basal medium (anaerobic buffer with resazurin) was immediately added

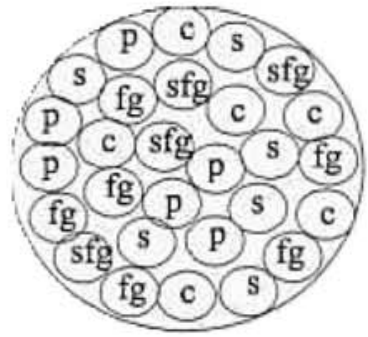

Legend:
c-clay
p-pozzolana
s-sepiolite
fg-foam glass
sfg-small foam glass

Figure 4-Microcarrier distribution in the MC section. and anaerobic conditions were ensured, as indicated by the maintenance of a nonpink color. The nonattached biomass was concentrated, resuspended in an anaerobic buffer and refrigerated for further activity measurement. At the end of methanogenic activity tests, retained volatile solids were determined.

Analytical Methods. Routine Analysis. Chemical oxygen demand, volatile solids (VS), and total solids were determined using procedures from Standard Methods (APHA et al., 1989). Volatile fatty acids were determined by high-performance liquid chromatography using a Chrompack column $(300 \mathrm{~mm} \times 6.5 \mathrm{~mm}$, Netherlands) and a mobile phase of $5 \mathrm{mM}$ sulfuric acid $\left(\mathrm{H}_{2} \mathrm{SO}_{4}\right)$ at 0.7 $\mathrm{mL} / \mathrm{min}$. The column was set at $40^{\circ} \mathrm{C}$ with detection at $210 \mathrm{~nm}$. Methane content of the biogas was measured by gas chromatography using a Chrompack Haysep Q (80 to 100 mesh) column, with $\mathrm{N}_{2}$ carrier gas at $30 \mathrm{~mL} / \mathrm{min}$ and a flame-ionization detector. Temperatures of the injection port, column, and flame-ionization detector were 120,40 , and $130^{\circ} \mathrm{C}$, respectively.

Activity Measurements. Methanogenic activity of the immobilized biomass was determined by measuring the initial rate of VFA degradation in batch assays. A stock VFA solution of acetate, propionate, and butyrate with a COD ratio of 24:34:41 was used, adding $0.26 \mathrm{~mL}$ VFA solution to the biomass to make up a working volume of $50 \mathrm{~mL}$, giving an initial COD of $2.65 \mathrm{~g} / \mathrm{L}$ in each vial. The basal medium was composed of $0.56 \mathrm{~g}$ cysteine hydrochloride/L, $0.05 \mathrm{~g}$ rezasurin $/ \mathrm{L}$, and $3.05 \mathrm{~g}$ sodium bicarbonate $/ \mathrm{L}$ and strict anaerobic conditions were ensured during its preparation. The vials were sealed with butyl-rubber stoppers, through which liquid samples were anaerobically removed with a hypodermic syringe. All tests were performed in duplicate and, for each support material, two control vials without added substrate accounted for the possibility of residual substrate degradation. The same procedure was used to measure specific methanogenic activity of the nonattached biomass.

Microscopy. A scanning electron microscope (Leica Cambridge S360, Netherlands) was used to observe the surface associated biomass. Samples were fixed with a $3 \%(w / v)$ glutaraldehyde solution in cacodylate buffer, $\mathrm{pH} 7.2$, and dehydrated with ascending concentration ethanol solutions. Before microscopic examination, samples were sputter-coated with gold.

\section{Results and Discussion}

Reactor Performance. Reactor start up was accomplished in 50 days by applying an organic loading rate of $8.2 \mathrm{~kg} \mathrm{COD} / \mathrm{m}^{3} \cdot \mathrm{d}$. Figure 5 represents the organic loading rate, COD removal efficiency, effluent COD-VFA evolution, and hydraulic retention time. All calculations were based on the MC section volume. After 50 days, the overall performance was $90 \%$ and methane content was between 61 and $65 \%$. The increase in organic loading rate on days 52 
and 81 did not affect the efficiency, indicating good stability and high methanogenic activity of the immobilized biomass.

Although suspended growth was absent because of the short retention time, a biofilm was observed adhering not only to the microcarrier surfaces but to all available surfaces, which contributed to the overall performance.

Biomass Retention. Immobilized biomass was quantified as VS. Values obtained for each material are presented in Table 2, expressed either as per fixed-bed volume or per dry weight. It was considered to be more appropriate to express attached biomass per unit of fixed-bed volume. For instance, foam glass, a light material when dry, had the largest amount of attached volatile solids per kilogram of dry material. However, a bed of sepiolite retained $60 \%$ more biomass than a similar bed (with equal particle diameter) of foam glass. Pozzolana, which retained 6.5 times less biomass than foam glass when examined in terms of weight, is not such a poor support when the assessment is made in terms of fixed-bed volume as it retained only $29 \%$ less biomass.

Comparison with reported values in the literature should be made carefully. In many works, the definition of units is not always clear. Also, as stated before, particle size is typically smaller than those used in the present work and substrate composition is variable. In spite of that, some reported values are presented in Table 2. Bonastre and Paris (1988) compared several supports for microbial colonization in batch tests, using a mixture
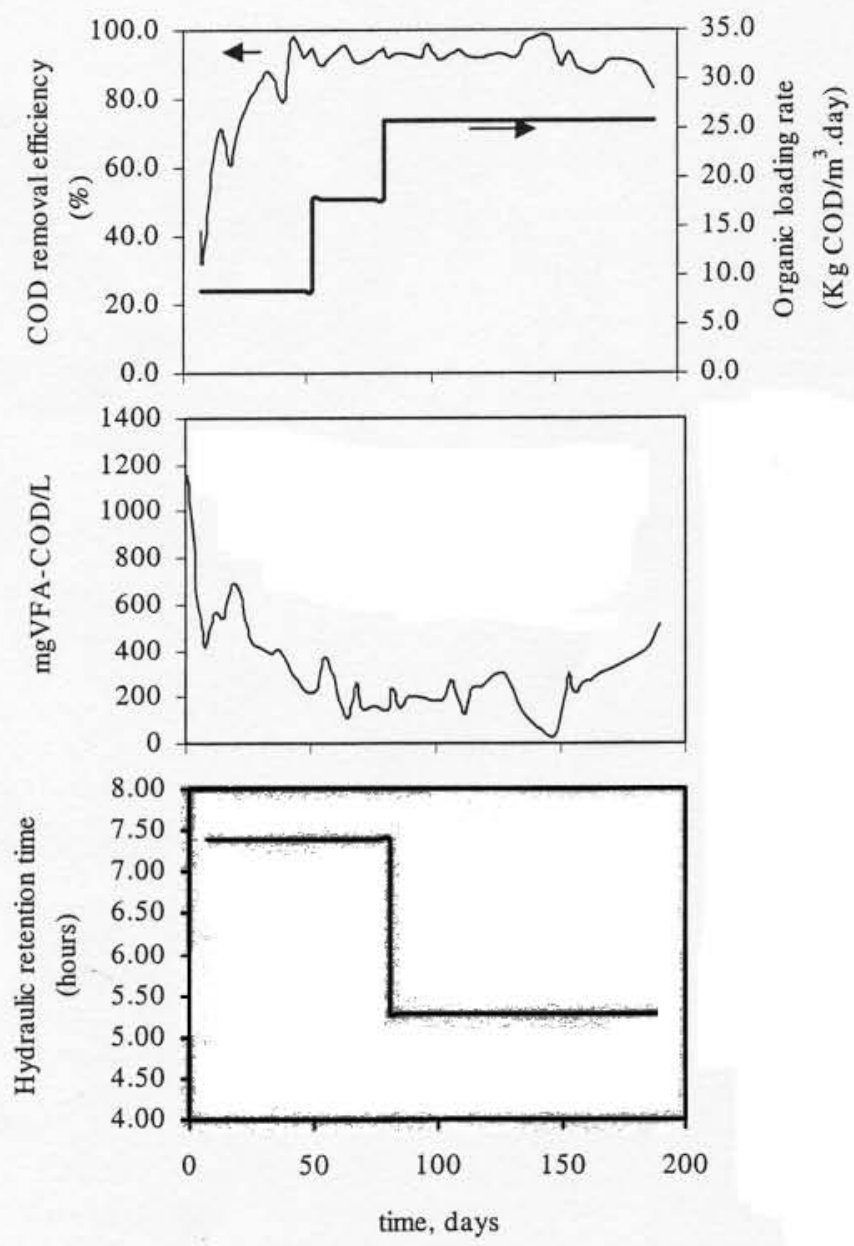

Figure 5-Operating conditions and performance.
Table 2-Attached biomass expressed as volatile solids per fixed-bed volume and dry weight $\pm 95 \%$ confidence interval. Comparison with previous works.

\begin{tabular}{|c|c|c|c|}
\hline $\begin{array}{l}\text { Support material } \\
\text { and average } \\
\text { particle size }\end{array}$ & $\begin{array}{l}\text { Attached } \\
\text { volatile solids, } \\
\text { gVS/L }\end{array}$ & $\begin{array}{c}\text { Attached } \\
\text { volatile solids, } \\
\text { gVS/kg (dry weight) }\end{array}$ & Reference \\
\hline Clay, $4.1 \mathrm{~mm}$ & $7.2 \pm 0.2$ & $16.5 \pm 0.7$ & This work \\
\hline $\begin{array}{c}\text { Foam glass, } \\
4.1 \mathrm{~mm}\end{array}$ & $9.4 \pm 0.7$ & $59.7 \pm 0.4$ & This work \\
\hline $\begin{array}{l}\text { Pozzolana, } \\
4.1 \mathrm{~mm}\end{array}$ & $6.7 \pm 0.2$ & $9.2 \pm 0.1$ & This work \\
\hline Sepiolite, $4.1 \mathrm{~mm}$ & $15.0 \pm 0.9$ & $30.5 \pm 2.6$ & This work \\
\hline Sepiolite, $1.5 \mathrm{~cm}$ & 15 & 9 & $\begin{array}{r}\text { Bonastre and } \\
\text { Paris, } 1988\end{array}$ \\
\hline Clay, $1.5 \mathrm{~cm}$ & 11 & 5 & \\
\hline Sand, $0.35 \mathrm{~mm}$ & - & 1.0 & \\
\hline Sand, $0.7 \mathrm{~mm}$ & - & 0.43 & \\
\hline $\mathrm{GAC},{ }^{\mathrm{a}} 0.7 \mathrm{~mm}$ & - & 19.1 & $\begin{array}{c}\text { Fox et al., } 1990 \\
\text { (adapted }^{\text {(a) }}\end{array}$ \\
\hline $\begin{array}{l}\text { Anthracite, } \\
0.7 \mathrm{~mm}\end{array}$ & - & 2.3 & \\
\hline Zeolite, $0.32 \mathrm{~mm}$ & $13.4-96.7$ & & Kuba et al., 1990 \\
\hline $\begin{array}{l}\text { Pozzolana, } \\
0.39 \mathrm{~mm}\end{array}$ & - & 3.4 & \\
\hline Biolite, $0.36 \mathrm{~mm}$ & - & 53 & $\begin{array}{c}\text { Garcia-Calderón } \\
\text { et al., } 1996\end{array}$ \\
\hline Kaolin, $0.38 \mathrm{~mm}$ & - & 0.9 & \\
\hline
\end{tabular}

a $\mathrm{GAC}=$ granular activated carbon.

b Biomass values, originally expressed as carbohydrates $\left(\mathrm{CH}_{2} \mathrm{O}\right)$, were converted to COD and then to VS, assuming biomass elemental composition as $\mathrm{C}_{5} \mathrm{H}_{7} \mathrm{O}_{2} \mathrm{~N}$.

of acetate and propionate as a substrate. Fox et al. (1990) operated four acetate-fed, expanded-bed anaerobic reactors and concluded that surface roughness was critical to biofilm development during start up. They observed a faster biomass accumulation on granular activated carbon (GAC) than on sand particles and the shear-loss coefficient observed for GAC was 4.9 to $16.2 \%$ smaller than for sand and anthracite. Kuba et al. (1990) operated a fluidized-bed reactor with a synthetic zeolite as the support material and a mixture of acetate, propionate, and butyrate as the substrate. They found a higher amount of VS attached to the particles than the estimated active biomass concentration calculated from kinetic batch assays. Garcia-Calderón et al. (1996) also concluded that rough-surface materials accumulate more biomass than smoothsurface materials, but observed similar performance for three reactors operating with different microcarriers. In spite of the greater amount of biomass measured on biolite, these authors observed that a thinner but more active biofilm developed on pozzolana and kaolin reactors, causing an undistinguished overall performance.

It was observed that total available internal porous volume for biomass (measured by the difference between water and mercury penetration and expressed per liter of fixed bed) was insufficient by itself to quantify the amount of biomass retained (Figure 6). In fact, foam glass, the most porous material tested, did not retain the greatest amount of biomass. Yee et al. (1992) found that pore size distribution and surface area are additional physical parameters that, concomitantly with the internal porous volume, determine cell retention capacity of porous microcarriers.

Scanning electron microphotographs were taken of each kind of microcarrier without biomass (Figure 7). Comparing the surface appearance of the different microcarriers it can be observed that 


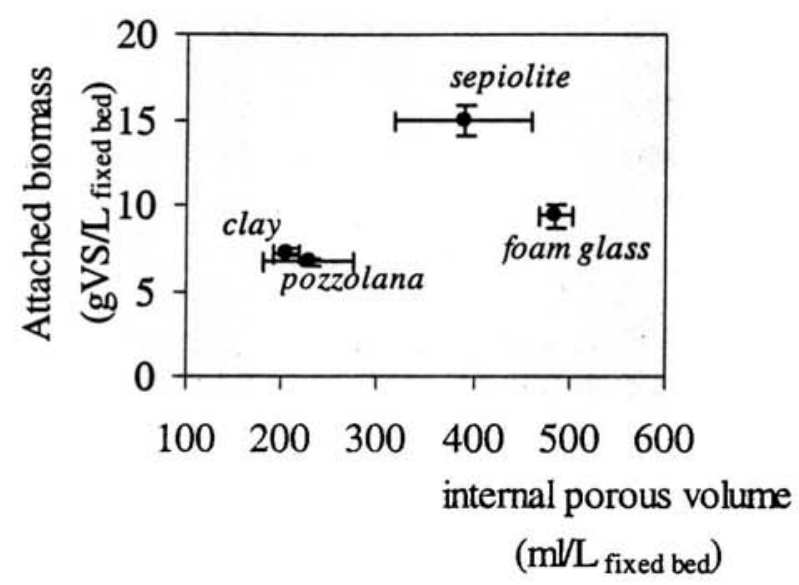

Figure 6-Effect of internal porous volume on attached biomass.

foam glass has the largest pores and a relatively smooth surface whereas pozzolana, clay, and sepiolite, in this order, have progressively smaller pores and rougher surfaces. In Table 3 , attached biomass is expressed per internal porous volume unit. This parameter allows differentiation and classification of the internal porous volume for biomass accumulation. Thus, the best-fitted internal
Table 3-Attached biomass concentration, expressed per internal porous volume ( $\pm 95 \%$ confidence interval).

\begin{tabular}{lc}
\hline \multicolumn{1}{c}{ Material } & $\begin{array}{c}\text { Attached biomass, } \\
\text { g VS/L }\end{array}$ \\
\hline Sepiolite & $38.4 \pm 2.4$ \\
Clay & $35.1 \pm 1.0$ \\
Pozzolana & $29.3 \pm 1.3$ \\
Foam glass & $19.3 \pm 1.4$ \\
\hline
\end{tabular}

porous volume was obtained for sepiolite followed by clay, pozzolana, and foam glass. Comparing Table 3 and Figure 7, the superior capacity of rough surfaces with cell size crevices for biomass retention is evident.

The conclusion that sepiolite is an efficient microcarrier for biomass immobilization is in accordance with early reported works. Huysman et al. (1983) observed that sepiolite was the most efficient material for microbial colonization when compared to glass beads, expanded clay, activated carbon, and zeolite. The amount of macro- and micropores and the surface roughness of sepiolite were suggested to be important factors for its ability to achieve a good and fast microbial colonization (Muñoz et al., 1994, and Shimp and Pfaender, 1982).

Figure 8 shows scanning electron microphotographs of colo-
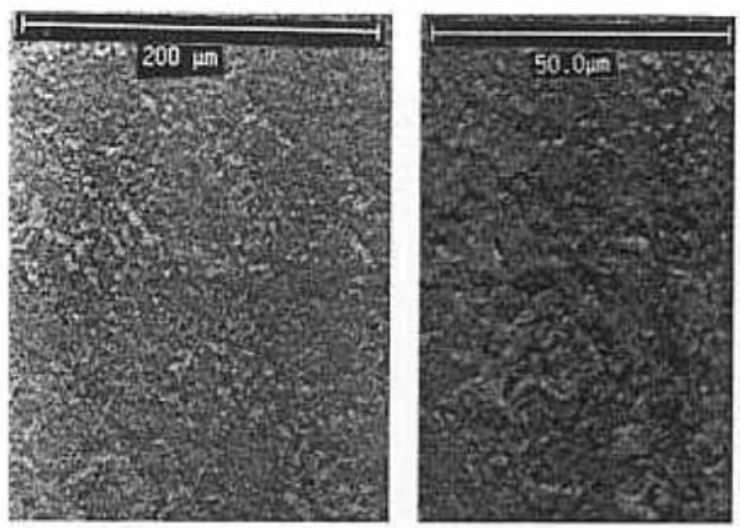

Sepiolite

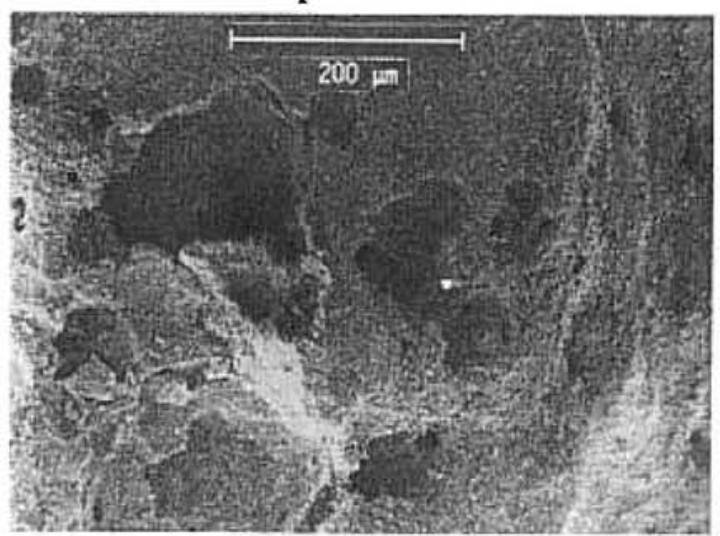

Pozzolana

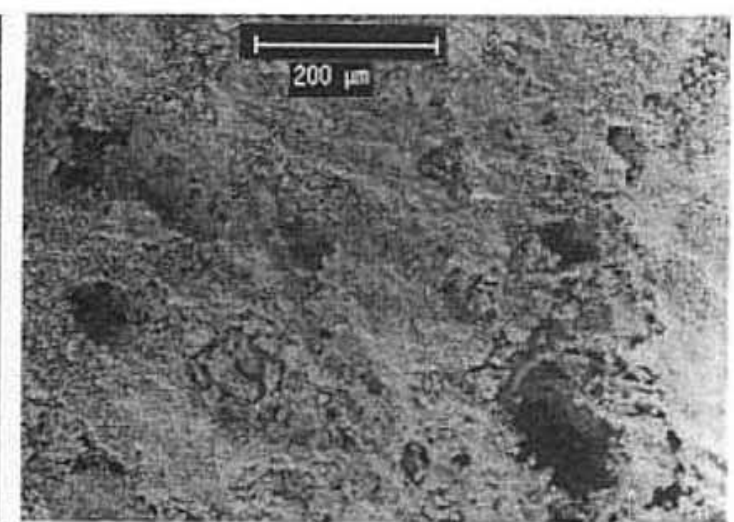

Clay

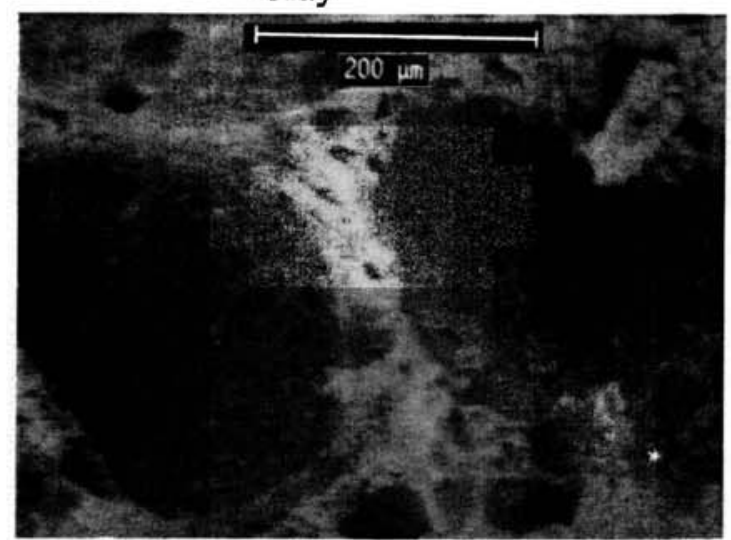

Foam glass

Figure 7-Scanning electron microphotographs of the microcarriers (clean surfaces). 

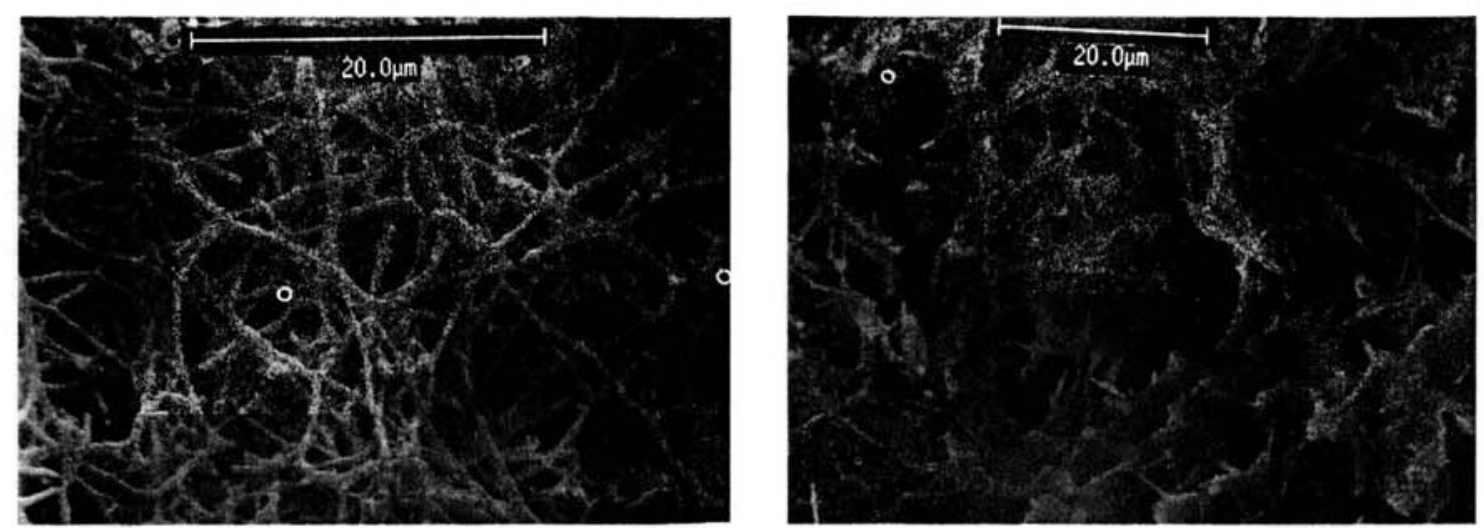

Sepiolite
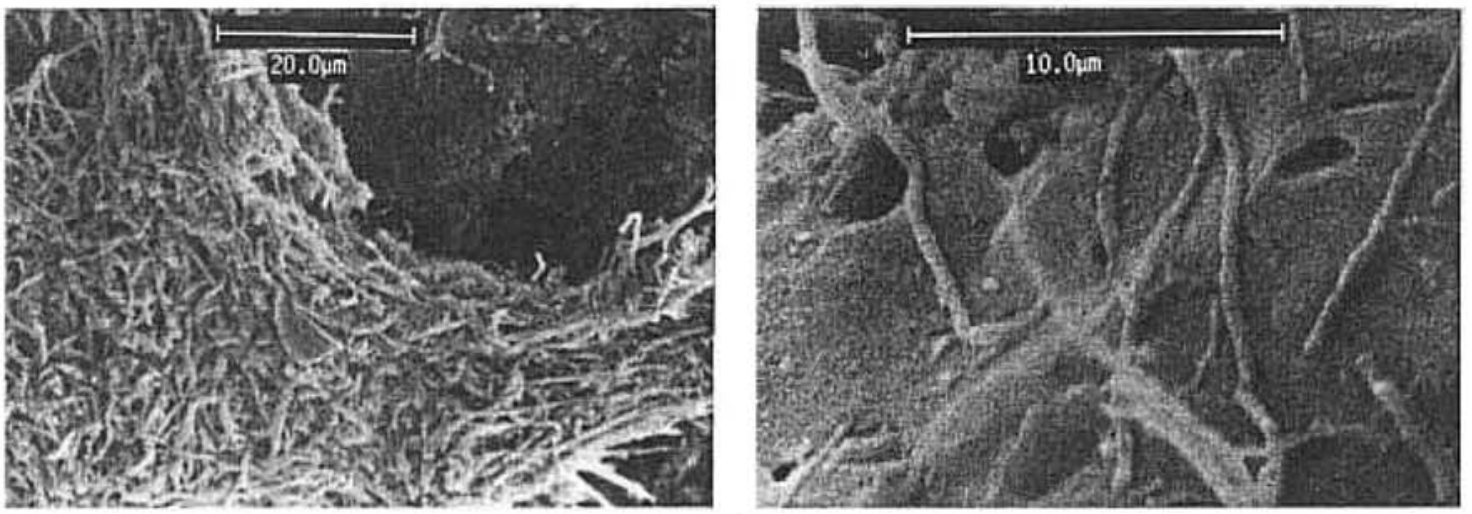

Clay
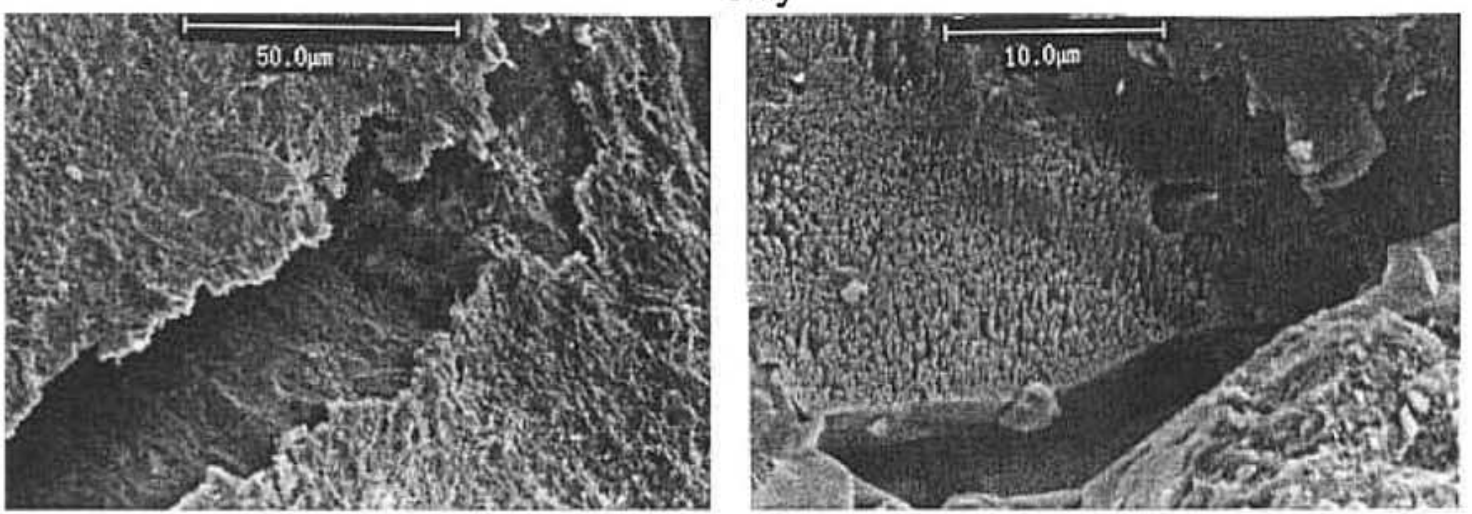

Pozzolana
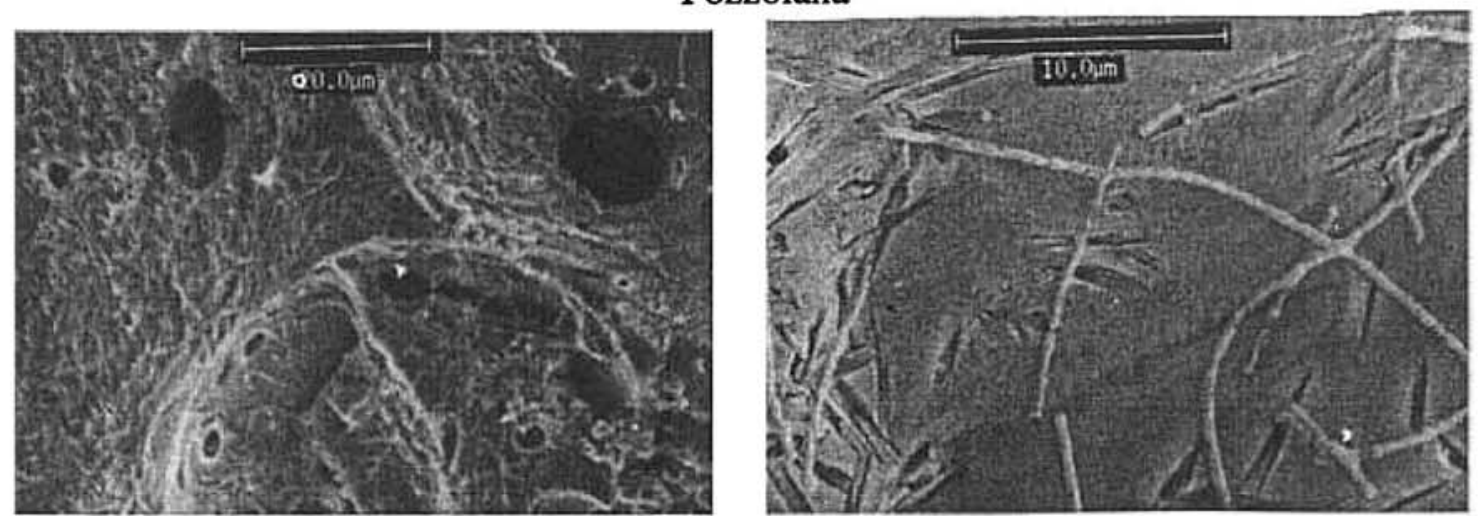

Foam glass

(a)

(b) 
Table 4-Specific methanogenic activity of immobilized biomass on different microcarriers $( \pm 95 \%$ confidence interval).

\begin{tabular}{lccc}
\hline & $\begin{array}{c}\text { SMA, } \\
\text { g VFA-COD/g } \\
\text { VS }\end{array}$ & $\begin{array}{c}\text { SMA } \\
\text { reduction, } \\
\%\end{array}$ & $\begin{array}{c}\text { SMA, } \\
\text { M VFA-COD/d }\end{array}$ \\
\hline Clay & $0.329 \pm 0.003$ & 5.4 & $2.37 \pm 0.07$ \\
Foam glass & $0.289 \pm 0.010$ & 17.0 & $2.71 \pm 0.22$ \\
Pozzolana & $0.340 \pm 0.038$ & 2.3 & $2.27 \pm 0.26$ \\
$\begin{array}{l}\text { Sepiolite } \\
\text { Nonattached } \\
\text { biomass }\end{array}$ & $0.173 \pm 0.007$ & 50.3 & $2.59 \pm 0.19$ \\
\hline
\end{tabular}

nized surfaces for all materials studied. These microphotographs revealed that the biofilm was composed primarily of long rods of Methanosaeta-like bacteria (formerly Methanothrix). A thick biofilm typically was observed on external surfaces. However, microbial penetration inside the microcarriers was not evident for most of the materials (Figure $8 b$ ).

Methanogenic Activity. The specific methanogenic activity (SMA) for the immobilized biomass was compared with the activity of the nonattached biomass. Table 4 presents those values and the overall average methanogenic activity observed per fixedbed volume unit. It was observed in all cases that biomass attached to the microcarriers suffered from an inhibition relative to the entrapped biomass. It is evident from Table 4 that sepiolite was the most inhibitory material, with a loss of $50 \%$ in the average specific methanogenic activity. On the other hand, considering the $95 \%$ confidence intervals associated, the effect of clay and pozzolana was not so evident.

Overall methanogenic activity of the different colonized microcarriers is not markedly different (Table 4 , last column), with a maximum difference of $19 \%$ between the two extreme values. In fact, a compensatory effect was observed between the SMA and the total amount of biomass determined as attached VS. This effect is evidenced by the negative-slope linear correlation between SMA and attached biomass (Figure 9). This inverse relationship between SMA and attached biomass indicates that thicker biofilms like those found in sepiolite and foam glass have a loss of activity relative to thinner biofilms, suggesting that, in those cases, the biofilm was only partially penetrated by the substrate. Diffusion limitations that provoke a sharp decrease of substrate concentration inside the biofilm affect the activity of the internal layers, thereby resulting in a loss in overall biofilm activity. On the other hand, the accumulation of inert organic matter (e.g., extracellular polymers) indirectly affects the specific activity by overestimating biomass measured as volatile solids. Garcia-Calderón et al. (1996) found that, despite variations in the amount of attached biomass, overall performance for three different reactors was similar, indicating a higher specific methanogenic activity for thinner biofilms. Kuba et al.(1990) also reported estimated active biomass concentrations smaller than the measured attached VS as a result of the accumulation of inert organic matter. In clay and pozzolana, a thinner biofilm with a higher specific methanogenic activity was observed, suggesting that on these materials the biofilm is highly

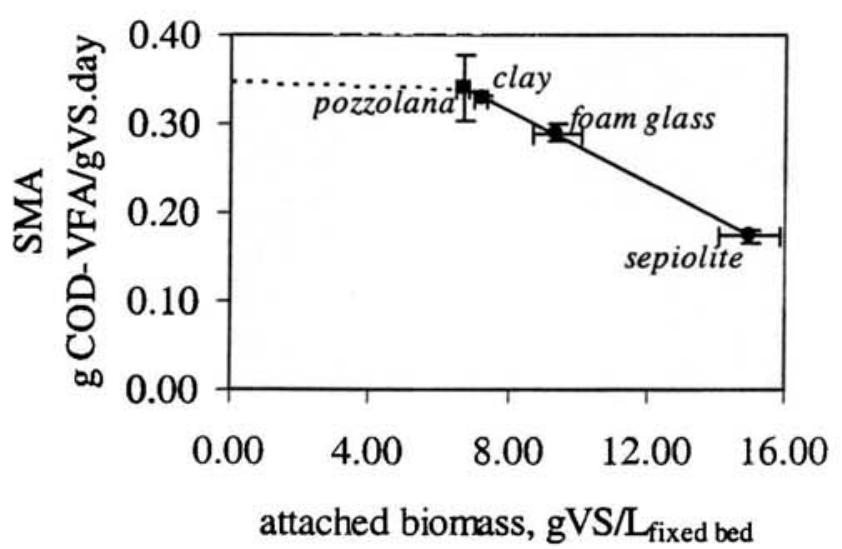

Figure 9-SMA vs attached biomass. Extrapolated value represents nonattached biomass activity.

active and fully penetrated by the substrate. The reduction of SMA relative to the suspended biomass in these materials was not significant, as can be seen in Table 4.

Possible chemical interaction between the biomass and mineral microcarriers should also be considered. Inhibitory and stimulatory effects of microcarriers on the methanogenic consortia have been previously reported by Bonastre and Paris (1988). They found that red clay had a strong inhibitory effect on specific methanogenic activity, which was attributed to the possible release of some components to the medium. Also, Murray and Van den Berg (1981) found a stimulatory effect using the same kind of material. However, the influence of chemical composition of mineral supports is probably more relevant in the absence of trace minerals, which was not the case in the present work.

On the other hand, the physicochemical environment encountered by microorganisms at solid-liquid interfaces can affect their physiological characteristics, altering the expression of some genes either in a positive or negative way (Marshall and Goodman, 1994).

To identify the trophic group that was the most affected by immobilization, acetate, propionate, and butyrate degradation rates were determined and compared for the biomasses adhered to different materials and for nonattached biomass (Table 5). Acetoclastic bacteria were the most affected bacteria, with a loss in their specific acetate degradation activity from $48 \%$ (foam glass and pozzolana) to $73 \%$ (sepiolite). These results confirm that, under mesophilic conditions, acetoclastic bacteria represent one of the weakest trophic groups in the bacterial community developed in anaerobic digesters. Propionate degradation activity was stimulated for the clay, foam glass, and pozzolana but was inhibited for sepiolite, whereas butyrate degradation activity was stimulated for all materials (between 84 and $110 \%$ ). These results indicate that immobilization had a positive effect on syntrophic activity that is governed by hydrogen partial pressure. Values less than 10 and $100 \mathrm{~Pa}$ should be maintained for propionate and butyrate degradation, respectively (McInerney and Bryant, 1980), which is achieved by a syntrophic association between butyrate or propionate degraders (hydrogen producers) and the methanogenic hy-

Figure 8-Colonized surfaces of different microcarriers: (a) external surface and (b) internal surface. 
Table 5-Volatile fatty acid degradation rate for the immobilized biomass $\pm 95 \%$ confidence interval (percent of variation referred to the nonattached biomass).

\begin{tabular}{|c|c|c|c|}
\hline Microcarrier & $\begin{array}{c}\text { Acetate degradation rate, } \\
\mathrm{mg} / \mathrm{g} \text { VS } \\
\text { attached } \cdot \mathrm{h}\end{array}$ & $\begin{array}{l}\text { Propionate degradation rate, } \\
\text { mg/g VS } \\
\text { attached } \cdot h\end{array}$ & $\begin{array}{c}\text { Butyrate degradation rate, } \\
\mathrm{mg} / \mathrm{g} \text { VS }\end{array}$ \\
\hline Clay & $5.920 \pm 0.002(-58.8 \%)$ & $5.005 \pm 0.128(+108.6 \%)$ & $1.131 \pm 0.009(+94.3 \%)$ \\
\hline Foam glass & $7.410 \pm 0.190(-48.4 \%)$ & $4.384 \pm 0.049(+82.7 \%)$ & $1.076 \pm 0.103(+84.8 \%)$ \\
\hline Pozzolana & $7.473 \pm 0.519(-48.0 \%)$ & $4.356 \pm 0.382(+81.6 \%)$ & $1.225 \pm 0.075(+110.5 \%)$ \\
\hline Sepiolite & $3.878 \pm 0.073(-73.0 \%)$ & $1.480 \pm 0.072(-38.3 \%)$ & $1.169 \pm 0.087(+100.9 \%)$ \\
\hline Nonattached biomass & $14.36 \pm 2.68$ & $2.399 \pm 0.056$ & $0.582 \pm 0.218$ \\
\hline
\end{tabular}

drogenotrophic, or sulfate-reducing, bacteria (hydrogen consumers) (Dolfing, 1988). As suggested for the granulation process, biofilm formation on a surface can provide a suitable environment for syntrophic associations because of the denser spatial arrangement of bacteria relative to dispersed biomass. The distance between bacteria involved in the syntrophic association can affect their cooperation, with a minimum distance optimal (Gujer and Zehnder, 1983). Schink and Thauer (1988) used this argument to explain the granulation phenomenon.

In the present work, the increase in butyrate and propionate degradation rates (up to $+110 \%$ of the adhered biomass relative to the suspended biomass) can be partially explained by the better hydrogen environment, relative to the environment of the nonattached biomass. Furthermore, if, as suggested for granular biomass (Fang, 1997, and Guiot et al., 1992), a layered concentric consortium structure exists for the biofilms, with acetoclastic bacteria located at the deepest zones, it is understandable that these bacteria would be the most affected by mass-transfer diffusion limitations. However, the scanning electron microphotographs did not corroborate this hypothesis.

\section{Conclusions}

The bioreactor designed for comparison of microcarriers proved to be easily operated, providing information about biomass retention capacity of different microcarriers. Although it has been applied to an anaerobic consortium, other applications can be envisaged either for anaerobic or aerobic processes.

The comparison of four porous microcarriers, clay, foam glass, pozzolana, and sepiolite, led to the conclusion that sepiolite had the greatest microbial retention capacity followed by foam glass, clay, then pozzolana, when expressed per fixed-bed volume unit. Sepiolite had the roughest surface and the best internal porous volume for biomass colonization, whereas foam glass had larger pores, a relatively smooth surface, and exhibited the poorest internal volume for biomass accumulation.

For all of the microcarriers, the SMA of the attached biomass suffered from an inhibition relative to the nonattached biomass. An inverse linear relationship between SMA and attached biomass concentration was observed, leading to a mostly uniform overall methanogenic activity for the different colonized microcarriers. In sepiolite and foam glass, the biofilm was thick but the SMA was reduced (50 and $17 \%$, respectively) relative to the suspended biomass, suggesting a biofilm partially penetrated by the substrate. This reduction is likely the result of diffusion limitations. In pozzolana and clay, a thin but active biofilm was obtained.

Although overall methanogenic activity was reduced in the immobilized biomass, the specific acetoclastic activity was severely affected, with 48 to $73 \%$ reduction relative to nonattached biomass. However, syntrophic activity was stimulated by adhesion. The hypothesis of a layered structure of biofilms, as suggested for granular sludge, with the acetoclastic bacteria located at the deepest zones, would suggest that these would be the bacteria most affected by mass-transfer diffusion limitations. On the other hand, the better interspecies hydrogen transfer in immobilized forms of biomass compared to suspended biomass can explain the higher syntrophic activity. The possible release of nutrients can act either in a positive or negative manner, affecting microbial activity.

\section{Acknowledgments}

Authors. M. Madalena Alves is an assistant professor, Alcina Pereira is a Ph.D. student and Manuel Mota is a full professor at the Universidade do Minho, Centro de Engenharia BiológicaIBQF, Braga, Portugal. F. Fdz Polanco is a full professor at the Departamento de Ingenieria Química Ambiental, Universidad de Valladolid, Spain. J. Maggiolly Novais is a full professor at the Instituto Superior Técnico, Centro de Engenharia Biológica e química, Lisboa, Portugal. Correspondence should be addressed to Manuel Mota, Centro de Engenharia Biológica, Universidade do Minho, 4700 Braga, Portugal.

Submitted for publication October 3, 1997; revised manuscript submitted April 3, 1998; accepted for publication October 1, 1998.

The deadline to submit Discussions of this paper is June 15, 1999.

\section{References}

Alves, M.M.; Pereira, M.A.; Bellouti, M.; Álvares Pereira, R.M.; Mota Vieira, J.A.; Novais, J.M.; and Mota, M. (1998) A New Method to Study Interactions Between Biomass and Packing Material in Anaerobic Filters. Biotechnol. Tech., 12, 4, 277.

American Public Health Association, American Water Works Association, and Water Pollution Control Federation (1989) Standard Methods for the Examination of Water and Wastewater. 17th Ed., Washington, D.C.

Balaguer, M.D.; Vicent, M.T.; and Paris, J.M. (1991) Utilization of Pumice Stone as Support for the Anaerobic Treatment of Vinasse with a Fluidized Bed Reactor. Environ. Technol., 12, 1167.

Balaguer, M.D.; Vicent, M.T.; and Paris, J.M. (1992) Anaerobic Fluidized Bed Reactor with Sepiolite as Support for Anaerobic Treatment of Vinasse. Biotechnol. Lett., 14, 433.

Bonastre, N., and Paris, J.M. (1988) Colonization and Stimulation/Inhibition Properties of Different Supports Used in Anaerobic Fixed-Film Reactors. Environ. Technol. Lett., 9, 763.

Borja, R.; Banks, C.J.; Maestrojuan, G.M.; and Wang, Z. (1994) Antagonistic and Synergistic Effects of Two Mineral Support Particles on the Hydrolisis and Methanation of Wastewater in Immobilized Cell Anaerobic Digesters. Biotechnol. Lett., 16, 859.

Bryers, J.D. (1987) Biologically Active Surfaces: Processes Governing the Formation and Persistence of Biofilms. Biotechnol. Prog., 3, 57. 
Dolfing, J. (1988) Acetogenesis. In Biology of Anaerobic Microorganisms. A.J.B. Zenhder (Ed.), Wiley \& Sons, New York, N.Y., 417.

Fang, H.H.P. (1997) Microbial Distribution and Syntrophic Association in UASB Granules. Proc. 8th Int. Conf. Anaerobic Digestion, Sendai, Jpn., 1, 83.

Fox, P.; Suidan, M.T.; and Bandy, J.T. (1990) A Comparison of Media Types in Acetate Fed Expanded-Bed Anaerobic Reactors. Water Res. (G.B.), 24, 827.

Garcia-Calderon, D.; Buffière, P.; Moletta, R.; and Elmaleh, S. (1996) Comparison of Three Granular Support Materials for Anaerobic Fluidized Bed Systems. Biotechnol. Lett., 18, 6, 731.

Guiot, S.R.; Pauss, A.; and Costerton, J.W. (1992) A Structured Model of the Anaerobic Granule Consortium. Water Sci. Technol., 25, 7, 1.

Gujer, W., and Zehnder, A.J.B. (1983) Conversion Processes in Anaerobic Digestion. Water Sci. Technol., 15, 127.

Heijnen, J.J.; Mulder, A.; Enger, W.; and Hoeks, F. (1986) Review on the Application of Anaerobic Fluidized Bed Reactors in Waste-Water Treatment. Proc. Anaerobic Treatment Grown-Up Technol., AQUATEC'86, Ind. Presentations, B.V. Schiedam, 159.

Huysman, P.; Van Meenen, P.; Van Assche, P.; and Verstraete, W. (1983) Factors Affecting Colonization of Nonporous and Porous Packing Materials in Model Upflow Methane Reactors. Biotechnol. Lett., 5, 643.

Iza, J.; Garcia, P.A.; Sanz, I.; Hernando, S.; and Polanco, F.-Fdz. (1988) Anaerobic Fluidized Bed Reactors (AFBR): Performance and Hydraulic Behaviour. Proc. Sth Int. Symp. Anaerobic Digestion, E.R. Hall and P.N. Hobson (Eds.), Bolonha, It., 155.

Jördening, H.J. (1992) Anaerobic Biofilms in Fluidized Bed Reactors. In Biofilms-Science and Technology. L.F. Melo, T.R. Bott, M. Fletcher, and B. Capdeville (Eds.), Nato ASI Series, Kluwer Academic Publishers, Dordrecht, Neth., 435.

Kuba, T.; Furumai, H.; and Kusuda, T. (1990) A Kinetic Study on Methanogenesis by Attached Biomass in a Fluidized Bed. Water Res. (G.B.), 24, 1365 .

Maestrojuán, G.M., and Fiestas, J.A. (1988) A Study of the Behaviour of Anaerobic Bacteria in the Presence of Diverse Materials Usable as Support. Proc. Sth Int. Symp. Anaerobic Digestion, A. Tilche and A. Rozzi (Eds.), Bolonha, It., 129.

Marshall, K.C., and Goodman, A.E. (1994) Effects of Adhesion on Microbial Cell Physiology. Colloids Surf. B., 2, 1.

McInerney, M.J., and Bryant, M.P. (1980) Basic Principle of Bioconversion in Anaerobic Digestion and Methanogenesis. In Biomass Conversion Processes for Energy and Fuels. S. Sofer and O. Zaborsky (Eds.), Plenum Press, New York, N.Y., 277.
Messing, R.A., and Oppermann, R.A. (1979) Pore Dimensions for Accumulating Biomass. I. Microbes that Reproduce by Fission or by Budding. Biotechnol. Bioeng., 21, 49.

Muñoz, M.A.; Sanchez, J.M.; Rodriguez-Maroto, J.M.; Moriñigo, M.A.; and Borrego, J.J. (1994) Evaluation of the Use of Sepiolite to Optimize the Methanogenesis from Anaerobic Domestic Sludges in Laboratory Conditions. Water Res. (G.B.), 28, 1, 195.

Murray, W.D., and Van den Berg, L. (1981) Effect of Support Material on the Development of Microbial Fixed Films Converting Acetic Acid to Methane. J. Appl. Bacteriol., 51, 257.

Petrozzi, S.; Dunn, I.J.; Heinzle, E.; and Kut, O.M. (1991) Carrier Influence in Anaerobic Biofilm Fluidized Beds for Treating Vapor Condensate from the Sulfite Cellulose Process. Can. J. Chem. Eng., 69, 527.

Rittmann, B.E. (1982) The Effect of Shear Stress on Biofilm Loss Rate. Biotechnol. Bioeng., 24, 501.

Rouxhet, P.G., and Mozes, N. (1990) Physical Chemistry of the Interface Between Attached Microorganisms and Their Support. Water Sci. Technol. (G.B.), 22, 1.

Schink, B., and Thauer, R.K. (1988) Energetics of Syntrophic Methane Formation and the Influence of Aggregation. Proc. Granular Anaer. obic Sludge: Microbiol. Technol. (GASMAT) Workshop, G. Lettinga, A.J.B. Zehnder, J.T.C. Grotenhuis, and L.W. Hulshoff Pol (Eds.), Puduc Wageningen, Wageningen, Neth., 5.

Schraa, G., and Jewell, J.W. (1984) High Rate Conversions of Soluble Organics with a Thermophilic Anaerobic Attached Film Expanded Bed. J. Water Pollut. Control Fed., 56, 226.

Shimp, R.J., and Pfaender, F.K. (1982) Effect of Surface Area and Flow Rate on Marine Bacterial Growth in Activated Carbon Columns. Appl. Environ. Microbiol., 44, 2, 471.

Wang, S.-D., and Wang, D.I.C. (1988) Pore Dimension Effects in the Cell Loading of a Porous Carrier. Biotechnol. Bioeng., 33, 915.

Yee, C.J. (1990) Effects of Microcarriers on Performance and Kinetics of the Anaerobic Fluidized Bed Biofilm Reactor. Ph.D. thesis, Univ. Pa., Philadelphia.

Yee, C.J.; Hsu, Y.; and Shieh, W.K. (1992) Effects of Microcarriers Pore Characteristics on Methanogenic Fluidized Bed Performance. Water Res. (G.B.), 26, 1119.

Zehnder, A.J.B.; Huser, B.A.; Brock, T.D.; and Wuhrmann, K. (1980) Characterization of an Acetate-Decarboxylating, Non-Hydrogen-Oxidizing Methane Bacterium. Arch. Microbiol., 124, 1. 